\title{
BACTÉRIAS ENDOFÍTICAS POTENCIALIZAM O CRESCIMENTO E MODULAM NÍVEIS DE CA2+ E K+ EM TOMATE CEREJA
}

\section{ARTIGO ORIGINAL}

SILVA, Rachel Helena Gachet ${ }^{1}$, RODRIGUES, Beatriz de Arruda², MANCUSO, Luigi Nogueira ${ }^{3}$, ARAÚJO, Suellen Aparecida Godoy ${ }^{4}$, BARREIRO, Carlos Eduardo Andrade $^{5}$, ALVES, Genoilson de Brito ${ }^{6}$

SILVA, Rachel Helena Gachet. Et al. Bactérias endofíticas potencializam o crescimento e modulam níveis de Ca2+ E K+ em tomate cereja. Revista Científica Multidisciplinar Núcleo Do Conhecimento. Ano 06, Ed. 06, Vol. 13, pp. 35-50. Junho de 2021. ISSN: 2448-0959, Link de acesso:

https://www.nucleodoconhecimento.com.br/biologia/tomate-cereja, DOI: 10.32749/nucleodoconhecimento.com.br/biologia/tomate-cereja

\section{RESUMO}

Com a crescente necessidade de demanda alimentar, muitas técnicas foram desenvolvidas para garantir a qualidade das plantas, a busca por alternativas naturais reduzindo o uso de agrotóxicos é uma vertente atraente para o consumidor. Neste trabalho analisamos se a manipulação da microbiota natural, poderia promover algum ganho para a planta, sem uso de produtos adicionais. Isolamos bactérias presentes

\footnotetext{
1 Técnica em Química.

2 Técnica em Química.

${ }^{3}$ Técnica em Química.

${ }^{4}$ Técnica em Química.

${ }^{5}$ Coorientador. Pós-Graduação em Química, Graduação em Ciências Químicas.

${ }^{6}$ Orientador. Mestrado em Ciências (Biomedicina), Pós-Graduação em Análises Clínicas, Graduação em Ciências Biológicas.
} 
em caules e folhas (endofíticas) de plantas de tomate cereja e após cultivo in vitro inoculamos as bactérias e verificamos seu potencial como promotor de crescimento para novas plantas. Utilizamos três métodos para enxertar as bactérias: inoculação na semente (BS), inoculação no solo (BSO) e inoculação na semente e no solo simultaneamente (BSSO). A partir de 10 dias da inoculação mensuramos: a altura das plantas, contagem de unidades formadoras de colônias (UFC), concentração de potássio e cálcio por fotometria de chama e realizamos testes bioquímicos nas bactérias. Os resultados obtidos na contagem de UFC/g de planta, revelaram que o método de enxertia foi eficaz para aumentar a concentração de bactérias na planta. Nos modelos tratados com bactérias constatamos aumento nos níveis de $\mathrm{Ca}^{2+}$ de $1,54 \%$ e $10,23 \%$ nos grupos BS e BSO respectivamente. Houve incremento significativo na concentração de $\mathrm{K}^{+}$sendo de $56,20 \%$ no grupo BS, $71,56 \%$ no BSO e $72,50 \%$, no BSSO, respectivamente. Através do teste de indol verificamos a produção de triptofanase pelas bactérias, isto gera substrato para formação de ácido indolacético (AIA) pelas plantas, favorecendo seu crescimento.

Palavras-chaves: bactérias endofíticas, promotor de crescimento, manejo orgânico, agricultura biodinâmica.

\section{INTRODUÇÃO}

O Brasil ocupa o 9 lugar entre os países que mais produzem tomate no mundo (FAO, 2016). O tomate é a $12^{\mathrm{a}}$ commodity do país e um dos itens que representa $70 \%$ dos vegetais de maior consumo da população brasileira (ANVISA, 2016). Apesar da sua importância econômica, em torno de duzentas doenças e distúrbios fisiológicos já foram relatados afetando a tomaticultura em todo o mundo, fator que torna a cultura suscetível ao consumo intenso de agrotóxicos (LOPES e ÁVILA, 2005).

Sabe-se que muitos produtos químicos empregados na agricultura apresentam períodos residuais longos, favorecendo a contaminação dos solos e águas e a bioacumulação desses compostos ao longo das cadeias alimentares. Em 2008, a ANVISA (Agência Nacional de Vigilância Sanitária), por meio do Programa de Análise de Resíduos de Agrotóxicos em Alimentos (PARA) analisou 104 amostras de tomate 
e verificou que 18,27\% (19 amostras) estavam insatisfatórias, tanto pela presença de agrotóxicos acima do Limite Máximo de Resíduos (LMR) quanto pela presença de resíduos de agrotóxicos de uso não autorizado para a cultura. No Relatório das Análises de Amostras Monitoradas no período de 2013 a 2015 foi identificado a presença de resíduos em concentrações acima do LMR em 62 amostras de tomate e 200 amostras apresentaram agrotóxicos não autorizados, em um total de 720 amostras de tomate de mesa analisadas (ANVISA, 2016).

Os problemas inerentes à produção de tomate também foram constatados em uma pesquisa feita pelo grupo no Sítio José Uwada, localizado no município de Suzano, SP. Na pesquisa realizada com o produtor Jair Flesch foi relatado as dificuldades na produção orgânica de tomate cereja e salada. O produtor informou que desde julho de 2012, quando iniciou o cultivo de tomate, a produtividade vem sendo restringida, devido a ocorrência de doenças e alterações climáticas. Na entrevista, o produtor relatou que em outubro de 2017 houve um grande prejuízo ocasionado pelo aparecimento prematuro de doenças no ciclo do tomateiro, pelo excesso de umidade e variações súbitas de temperatura, resultando na colheita de menos de $1 \mathrm{Kg}$ de fruto por planta, mesmo o plantio sendo realizado em ambiente protegido.

O emprego de microrganismos endófitos (ou endofíticos) de plantas tem ganhado destaque na agricultura em meio a necessidade de aumentar a capacidade produtiva das plantas e diminuir os impactos no ambiente e na saúde humana. O interesse nesses microrganismos está relacionado com suas propriedades como a promoção de crescimento vegetal e o controle biológico de doenças de plantas, sendo apontada como uma alternativa econômica e ecologicamente sustentável que pode evitar ou reduzir os impactos negativos ao meio ambiente (SANTOS e VARAVALLO, 2011).

Esses microrganismos incluem principalmente bactérias e fungos que habitam o interior de folhas, caules e raízes de plantas, sem causar dano ao hospedeiro, diferenciando-se dessa forma dos microrganismos fitopatogênicos, que causam danos às plantas (AZEVEDO, 1998). Vários estudos acerca da utilização dos endófitos foram verificados na literatura. No que diz respeito ao crescimento vegetal, Barretti et al. (2008) identificaram o potencial de 53 isolados de bactérias endófitas 
obtidas de folhas, caules e raízes de tomate sadios como promotores de crescimento da cultura, constatando a capacidade do isolado UFV-E49 em favorecer o crescimento do seu hospedeiro, propiciando um incremento de $23,40 \%$ na altura, $105,8 \%$ na área foliar e de 19,5\% no número de folhas em relação às plantas testemunhas. Na seleção de bactérias endófitas, Barretti et al. (2009) relataram a atuação de quatro bactérias no controle da mancha bacteriana e da pinta preta e na promoção de crescimento das plantas do tomateiro, destacando-se a bactéria Serratia marcescens que proporcionou um aumento de $15,16 \%$ na altura das plantas em comparação às plantas testemunhas.

A capacidade de estimular o crescimento das plantas está associado a mecanismos diretos como a produção de hormônios de crescimento, a fixação de nitrogênio, absorção de nutrientes e indiretos como o controle de fitopatógenos (ROMEIRO et al., 2004). Como consequência, verifica-se um aumento na produção final, na taxa de germinação, incremento na altura, na concentração de nutrientes, entre outros (MARIANO et al., 2004).

O presente trabalho teve por objetivos avaliar e mensurar o crescimento de plantas de tomateiro com diferentes enxertos de bactérias endofíticas, analisando uma metodologia mais simples e eficaz de inoculação dos endófitos para promover o crescimento sustentável de plantas, com base nos princípios da Química Verde de uma produção agrícola sustentável.

\section{MATERIAL E MÉTODOS}

\subsection{ISOLAMENTO E CARACTERIZAÇÃO BIOQUÍMICA DAS BACTÉRIAS ENDÓFITAS}

As bactérias endófitas foram isoladas de plantas de tomateiro cedidas pelo Sítio José Uwada, localizado no município de Suzano, SP. O material vegetal fornecido pelo produtor constituía-se de caules e folhas de tomateiro da variedade cereja amarelo japonês e salada, provenientes de plantio orgânico. 
As amostras vegetais foram submetidas à desinfecção superficial para eliminação dos microrganismos epifíticos e outros microrganismos, mantendo-se apenas os endófitos. A desinfecção deu-se por meio de lavagem em água corrente, para retirada da sujidade, seguida de lavagens por imersão em solução de álcool etílico 70\%, por 3 minutos, em solução de hipoclorito de sódio $2,5 \%$, por 3 minutos, e lavagem com água deionizada, por três vezes (BARRETTI et al., 2009). Após a desinfecção, partes dos caules foram descartados a fim de evitar que os agentes de assepsia penetrassem nos fragmentos submetidos ao isolamento. Pequenos fragmentos dos caules e folhas foram adicionados em placas de Petri contendo meio ágar nutriente e incubados em estufa a $28^{\circ} \mathrm{C}$. O crescimento foi verificado 5 dias após a incubação e as colônias bacterianas desenvolvidas foram repicadas em ágar nutriente estéril para ampliar a população e possibilitar a realização dos testes sequenciais.

As bactérias endófitas foram classificadas quanto à forma, reação à coloração de Gram, teste de catalase e teste de indol. A caracterização foi realizada a fim de se verificar as particularidades bioquímicas dos endófitos dado a impossibilidade de realizar sua identificação. Dentre os testes executados apenas o teste de indol possui correlação com a capacidade de promoção de crescimento de plantas pelos microrganismos endófitos.

A técnica de Coloração de Gram foi realizada conforme descrito por Tortora et al. (2017). Primeiramente, colocou-se uma gota de água deionizada na superfície de uma lamínula de vidro. Em seguida, retirou-se uma amostra de colônias bacterianas com a alça de platina e espalhou-a sobre o líquido. O esfregaço foi fixado passando-se a lamínula sobre a chama de um bico de Bunsen. Os reagentes violeta de genciana, lugol, álcool etílico e fucsina/safranina foram aplicados sequencialmente em intervalos de 1 minuto e com lavagem do esfregaço com água de torneira entre as aplicações. Em seguida, secou-se a lamínula e observou-a em microscópio óptico onde evidenciando um predomínio de estreptobacilos Gram-positivos nas amostras (Figura 2A).

No teste da catalase, aplicou-se uma amostra de colônias bacterianas sobre em uma lamínula de vidro utilizando a alça de platina e, em seguida, pipetou-se uma gota de 
peróxido de hidrogênio $\left(\mathrm{H}_{2} \mathrm{O}_{2}\right) 3 \%$ sobre os endófitos. Posteriormente, observou-se a ocorrência da formação de bolhas (gás oxigênio), provenientes da degradação do peróxido de hidrogênio (Figura 2B).

O teste de indol foi realizado no tubo contendo o meio Rugai. Utilizando-se a alça de platina, retirou-se uma amostra das colônias endófitas. Em seguida, imergiu-se a alça com os endófitos na parte central do tubo contendo o meio Rugai até atingir sua profundidade. Retirou-se a alça lentamente e fez-se o estriamento na superfície do meio com o tubo inclinado. Posteriormente, incubou-se o tubo semiaberto a $28^{\circ} \mathrm{C}$. Quarenta e oito horas após a incubação adicionou-se 2 duas gotas do Reativo de Kovacs na parte interna da tampa do tubo e aguardou-se 1 minuto para o surgimento da cor vermelha caracterizando indol positivo.

\subsection{INOCULAÇÃO DAS BACTÉRIAS ENDÓFITAS}

Sementes de tomate cereja do cultivar carolina (Feltrin Sementes) foram utilizadas para o teste de indução de crescimento pelas bactérias endófitas. $O$ experimento foi realizado avaliando-se diferentes parâmetros para aplicação das bactérias endófitas. Os tratamentos consistiram na aplicação dos endófitos na semente (BS), no solo (BSO) e na semente e no solo (BSSO) simultaneamente por meio de uma suspensão das bactérias endófitas.

No preparo da suspensão bacteriana, retirou-se uma amostra de colônias endófitas preservadas em placa de Petri com a alça de platina, transferiu-as para um béquer contendo $250 \mathrm{~mL}$ de caldo nutriente e homogeneizou-se a suspensão com agitador magnético. Da suspensão obtida, transferiu-se $50 \mathrm{~mL}$ para um béquer, onde imergiuse as sementes, destinadas aos tratamentos BS e BSSO, por um período de 1 hora antes de serem plantadas. Em paralelo, inoculou-se o solo dos tratamentos BSO e BSSO com uma alíquota de $5 \mathrm{~mL}$ da suspensão restante utilizando-se uma pipeta de Pasteur.

O plantio foi realizado no dia 05 de junho de 2018 em um o solo preparado a partir de uma mistura de terra vegetal, húmus de minhoca e vermiculita, adicionando-se 
aproximadamente $10 \mathrm{~g}$ da mistura por célula de uma bandeja para mudas contendo 36 células. Após a enxertia com bactérias endófitas e o plantio, a bandeja de mudas foi levada à casa de vegetação (estufa) construída pelos alunos, onde permaneceu até o término do experimento, tendo-se efetuado o replantio 23 dias após a inoculação em um solo constituído de terra vegetal e húmus de minhoca. Posteriormente, foram realizados mais dois replantios: 58 dias e 108 dias após a inoculação.

FIGURA 1: Esquema dos tratamentos com as bactérias endófitas nas sementes de tomateiro e no solo.
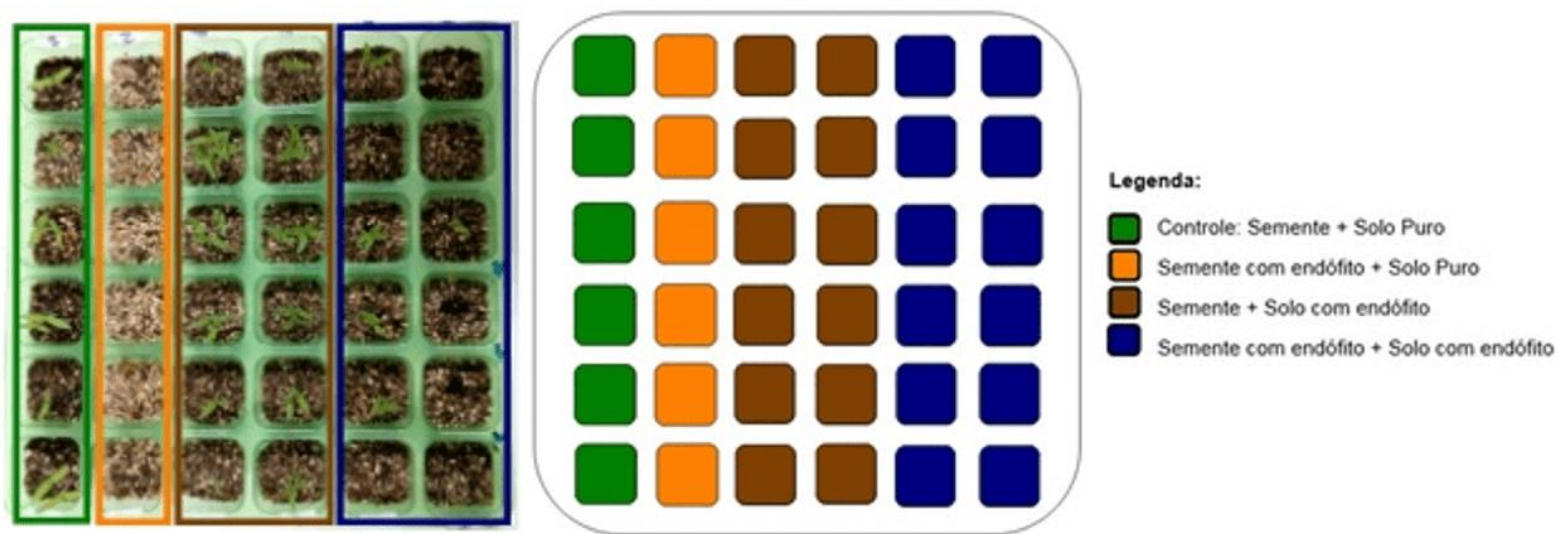

Fonte: Autoria própria (2017).

\subsection{QUANTIFICAÇÃO DE UNIDADES FORMADORAS DE COLÔNIAS (UFC) PELO MÉTODO POUR PLATE}

Para verificar o êxito na enxertia de bactérias endófitas foi realizado o método Pour Plate que corresponde uma medida direta do crescimento bacteriano nas plantas, sendo o resultado expresso em unidades formadoras de colônias (UFC) por grama de amostra.

No procedimento, coletou-se aleatoriamente cerca de $200 \mathrm{mg}$ de folhas adultas de cada tratamento e do grupo controle. Posteriormente realizou-se a lavagem com água de torneira, seguida de imersão das folhas sem pecíolo em solução de álcool etílico $70 \%$, por 3 minutos, solução de hipoclorito de sódio $2,5 \%$, por 3 minutos e água deionizada, por três vezes para a eliminação dos microrganismos epífitos. As folhas 
foram trituradas em água deionizada utilizando almofariz e pistilo e deixadas em repouso por 15 minutos para a dispersão dos endófitos. (BARRETTI et al., 2009). Em seguida, filtrou-se a mistura. Cerca de $1 \mathrm{~mL}$ do filtrado foi diluída em $9 \mathrm{~mL}$ de água deionizada no tubo Falcon (diluição 1:9). Em seguida, retirou-se uma amostra de 500 $\mu \mathrm{L}$, a qual foi espalhada em placa de Petri. Sobre a amostra foi vertido o meio ágar padrão para contagem, a aproximadamente $40^{\circ} \mathrm{C}$, homogeneizando-se com movimentos circulares. Após a solidificação do ágar, as placas foram incubadas em estufa a $28^{\circ} \mathrm{C}$ e depois de 48 horas procedeu-se com a contagem de UFC em um contador de colônias.

\subsection{ANÁLISE NUTRICIONAL DE POTÁSSIO E CÁLCIO NAS PLANTAS DO TOMATEIRO EMPREGANDO FOTOMETRIA DE CHAMA}

A análise nutricional objetivou verificar a concentração de potássio $(K)$ e cálcio $(\mathrm{Ca})$ nos tratamentos com os endófitos e no controle. A amostragem dos tecidos vegetais de cada tratamento e grupo controle foi realizada conforme a metodologia descrita em Métodos de Análise de Tecidos Vegetais da (CARMO et al., 2000) e Handbook of Reference Methods for Plant Analysis (1998) com adaptações. A leitura das amostras foi realizada no fotômetro de chama Digimed DM-62. As vidrarias utilizadas para análise foram lavadas com água de torneira por duas vezes e imergidas em solução de ácido clorídrico $(\mathrm{HCl}) 3 \mathrm{~mol} / \mathrm{L}$, por 30 minutos, lavadas com água deionizada e posteriormente secas.

Folhas jovens do tomateiro foram coletadas, armazenadas em sacos plásticos e, posteriormente, lavadas com água de torneira e água deionizada para retirada da sujidade. As amostras foram embaladas em sacos de papel e colocadas em estufa elétrica em temperaturas variando de 65 a $70^{\circ} \mathrm{C}$ por 24 horas. As amostras foram moídas utilizando almofariz e pistilo e, em seguida, foram peneiradas em peneira 20 mesh. A solubilização deu-se por via seca, onde aproximadamente $200 \mathrm{mg}$ de amostra de cada tratamento e controle foram transferidos para cadinhos de porcelana e incineradas em mufla elétrica, aumentando-se gradativamente a temperatura até $500^{\circ} \mathrm{C}\left(3,3^{\circ} \mathrm{C} / \mathrm{min}\right)$, por 2 a 4 horas até a obtenção de cinza branca. 
A cinza resultante foi dissolvida em $25 \mathrm{~mL}$ ácido nítrico $\left(\mathrm{HNO}_{3}\right) \quad 0,1 \mathrm{~mol} / \mathrm{L} \mathrm{e}$, em seguida, filtrada. Retirou-se $5 \mathrm{~mL}$ da amostra e diluiu-se em um balão volumétrico de $50 \mathrm{~mL}$ (diluição 1:9). Calibrou-se o fotômetro de chama com solução padrão 20 ppm de $\mathrm{K}$ e $\mathrm{Ca}$ e procedeu-se com a leitura das amostras no equipamento.

\subsection{AVALIAÇÃO DO CRESCIMENTO DAS PLANTAS DE TOMATEIRO}

As avaliações do crescimento das plantas iniciaram 10 dias após a enxertia das bactérias endófitas. Realizou-se as medições da altura partindo do caule até a folha mais alta. As medições referentes a etapa de germinação foram realizadas em um período de oito dias (15 de junho de 2018 a 22 de junho de 2018), durante três dias da semana (segunda-feira, quarta-feira e sexta-feira), totalizando 4 medições. As medições correspondentes à fase adulta até a frutificação ocorreram em um período de cinquenta e sete dias (02 de agosto de 2018 a 27 de setembro de 2018), com intervalo de quinze dias entre as medições, totalizando 5 medições.

\subsection{ANÁLISE ESTATÍSTICA}

A análise estatística foi obtida através do teste One-way ANOVA, seguido por análise do Teste de Bonferroni. Todas as análises estatísticas foram realizadas através do Software GraphPad Prism 5. Os asteriscos acima das linhas representam as diferenças significativas entre as barras indicadas com ${ }^{*} p<0,05,{ }^{* *} p<0,01$ e ${ }^{* * *} p<0,001$.

\section{RESULTADOS E DISCUSSÃO}

As bactérias endófitas isoladas de amostras do tomateiro provenientes do Sítio José Uwada foram identificadas em sua maioria como estreptobacilos, gram-positivo (Figura 2 A) e catalase positiva (Figura 2 B), podemos verificar o surgimento de bolhas ao compararmos com a parte inferior da figura que é o controle. 
FIGURA 2: Microscopia ótica evidenciando o teste de GRAM aumento de 1000X (A) e o teste de Catalase (B)
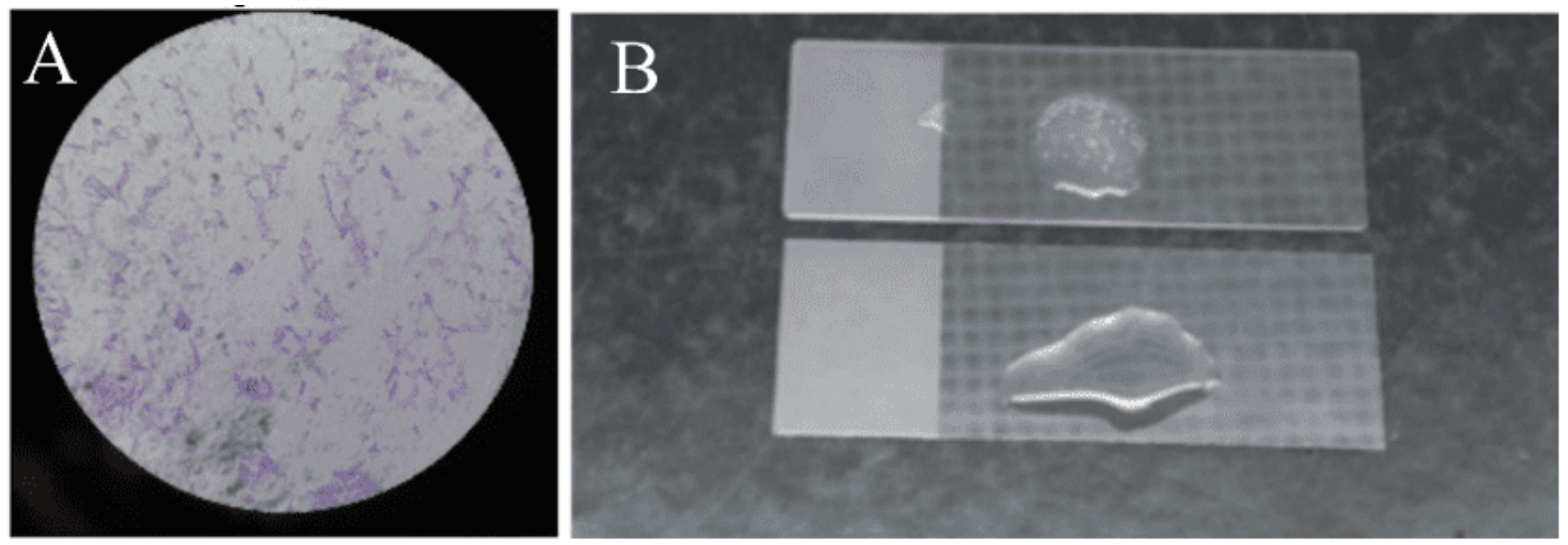

Fonte: Autoria própria (2017).

Os resultados obtidos na contagem de unidades formadoras de colônias (UFC) revelaram eficácia no método de enxertia das bactérias endofíticas. Realizando a contagem de UFC/g de planta, verificou-se um incremento médio de $72,50 \%$ no tratamento BSSO, seguido de $71,56 \%$ no BSO e $56,20 \%$ no tratamento BS, em relação ao controle (Figura 3). Verificamos que entre o grupo BSSO e BSO não há diferença estatística significativa, mesmo um grupo possuindo duas vias de inoculação e assim exposto a mais bactérias. Uma hipótese é que o tratamento BSSO tenha excedido o espaço anatômico disponível para a interação entre planta e bactéria, e por isso o resultado seja semelhante a única via do tratamento BS. 
FIGURA 3: Assimilação das bactérias pela planta - Unidades formadoras de colônias (UFC) em cada tratamento.

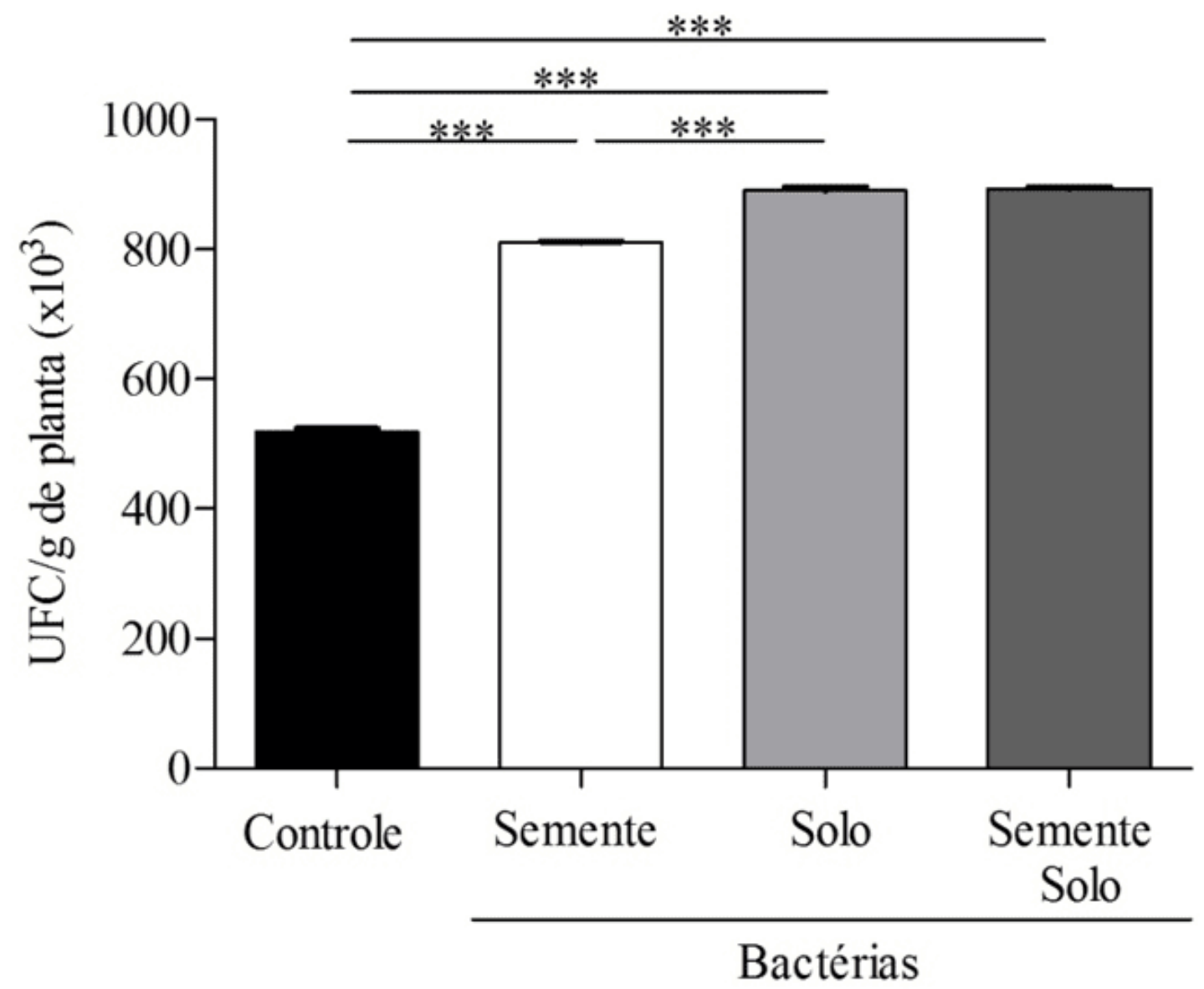

Fonte: Autoria própria (2017).

$\mathrm{Na}$ avaliação de crescimento das plantas, observou-se que os tratamentos BSO e BSSO apresentaram resultados estatisticamente próximos em relação à altura, no período de germinação (Figura 4). $O$ tratamento BS foi estatisticamente inferior aos demais grupos experimentais no estágio germinativo. É possível que as bactérias não possuam repertório de receptores de membrana adaptados para se fixar com eficiência as sementes até o momento do plantio. Na fase inicial o crescimento entre o controle e os tratados BS e BSSO são semelhantes, uma hipótese é de que as bactérias passam por um período de fase lag prolongado até conseguirem exercer suas funções básicas ou que talvez o número de bactérias não seja um fator que 
influencie diretamente no crescimento das plantas, por isso, realizamos os testes em períodos mais prolongados.

FIGURA 4: Análise estatística do crescimento durante a germinação.

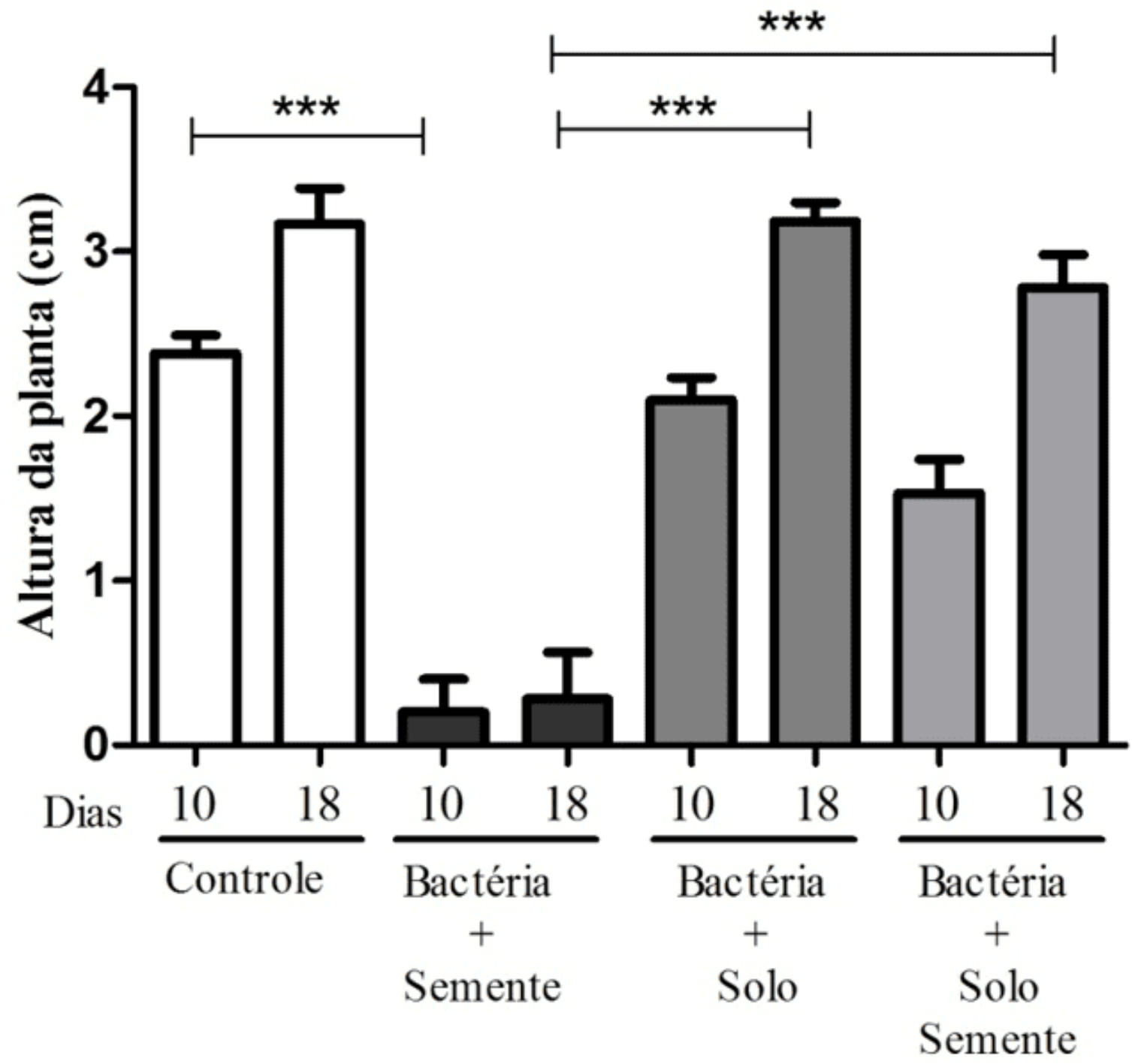

Fonte: Autoria própria (2017).

Em média, as plantas do controle apresentaram altura superior aos tratamentos com endófitos na maioria das medições correspondentes durante o período germinativo (Figura $5 \mathrm{~A}$ ). $\mathrm{O}$ tratamento BS apresentou uma média de altura inferior aos demais tratamentos e ao controle, mesmo havendo o aumento no número de bactérias endofíticas nas plantas pertencentes ao tratamento (Figura 3). 
Em etapa posterior a germinação, mensuramos o crescimento das plantas até a frutificação, verificou-se que os grupos experimentais BSSO e BSO tiveram um incremento na altura média das plantas em relação ao controle (Figura $5 \mathrm{~B}$ ). A comparação entre o BSSO e o controle aponta aumento de 1,22 vezes e ao comparar com o BS o aumento é de 2,55 vezes.

FIGURA 5: Média da altura das plantas no estágio de germinação (A) e replantio (B).
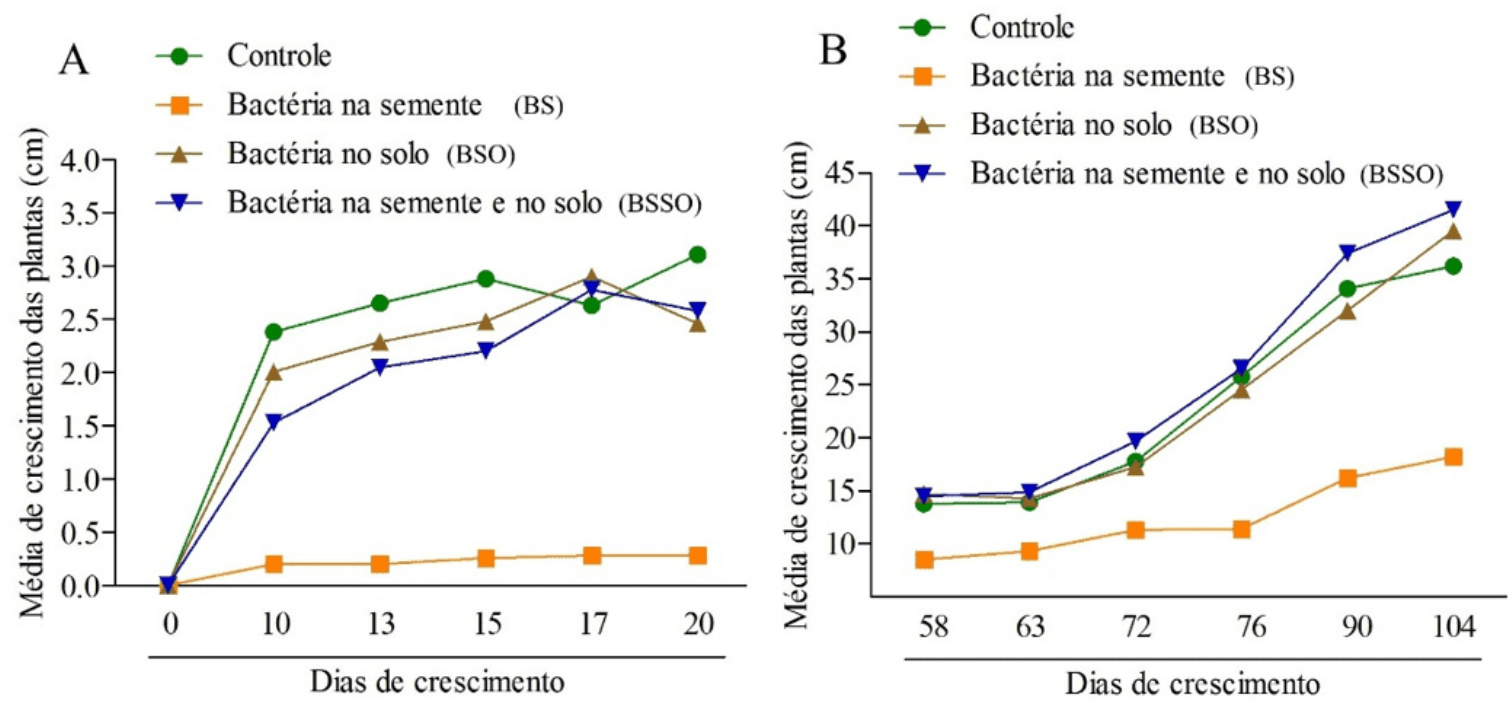

Fonte: Autoria própria (2017).

$\mathrm{Na}$ contagem de frutos no controle e nos grupos tratados, constatou-se que a produtividade das plantas pertencentes ao tratamento BSSO teve um incremento significativo de $45 \%$ em relação ao número de frutos total do controle (Figura 6). 
FIGURA 6: Número de frutos por grupo experimental e controle.

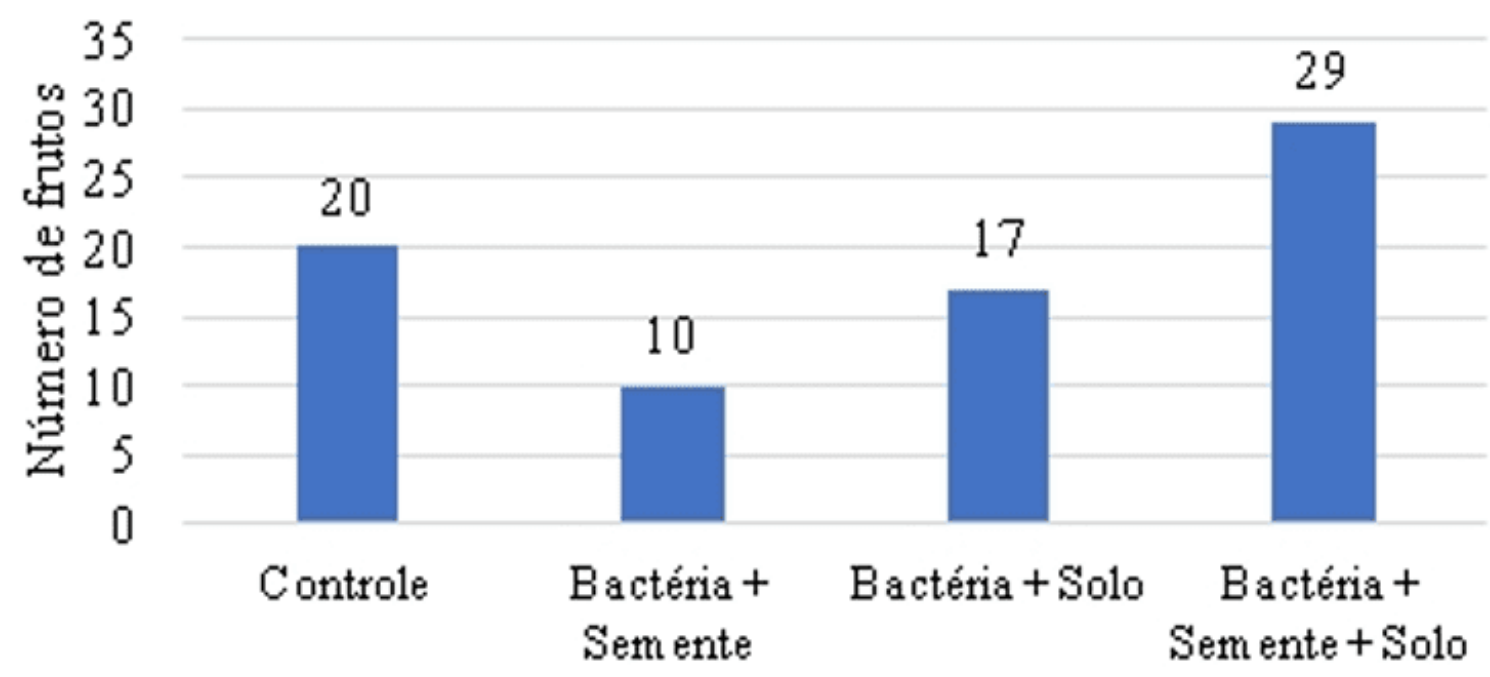

Fonte: Autoria própria (2017).

Segundo Mariano et al. (2004), a promoção de crescimento por microrganismos endófitos está relacionada diretamente a mecanismos como a produção de fitohormônios, aumento da absorção de água e nutrientes. Os resultados obtidos na análise nutricional dos tecidos vegetais (Figura 7) mostraram que o tratamento BSSO proporcionou um incremento de $17,72 \%$ na concentração de $\mathrm{K}$ e o tratamento BSO promoveu um aumento de $10,23 \%$ de $\mathrm{Ca}$ em relação ao controle, conforme os dados da Tabela 1. 
FIGURA 7: Concentração de $\mathrm{K}^{+}$e $\mathrm{Ca}^{2+}$ no controle e grupos experimentais.

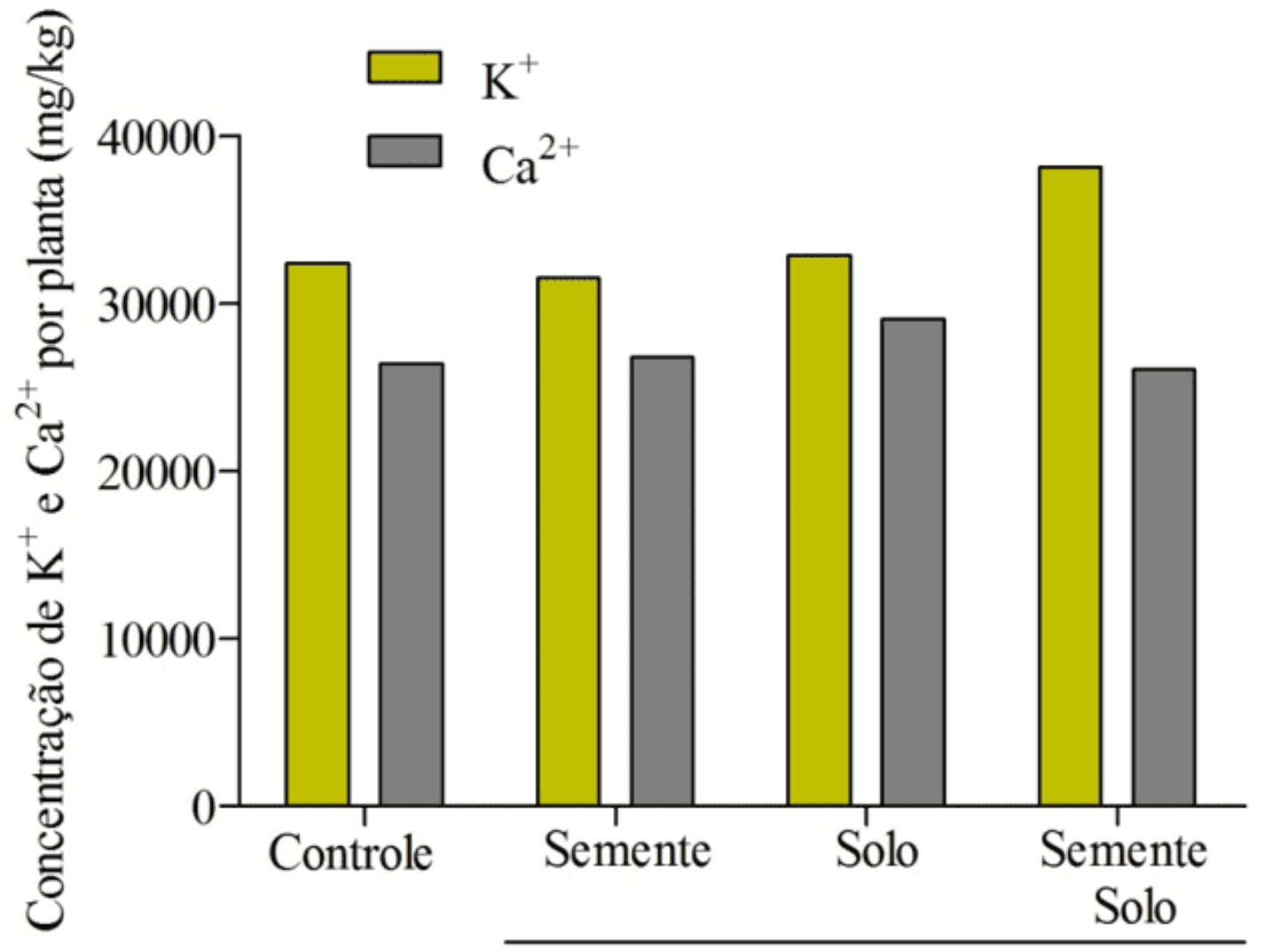

\section{Bactérias}

Fonte: Autoria própria (2017).

TABELA 1: Concentração de $\mathrm{Ke} \mathrm{Ca}$ ( $\mathrm{mg} / \mathrm{kg}$ de planta) nos tratamentos com bactérias endófitas e controle.

\begin{tabular}{|c|c|c|c|c|}
\hline Experimento & $\begin{array}{l}\text { Concentração de } \mathrm{K} \\
(\mathrm{mg} / \mathrm{kg}) \text { de planta }\end{array}$ & $\begin{array}{c}\text { Concentração de Ca } \\
(\mathrm{mg} / \mathrm{kg}) \text { de planta }\end{array}$ & $\begin{array}{c}\% \text { de } \mathrm{K} \text { em relação ao } \\
\text { controle }\end{array}$ & $\begin{array}{c}\% \text { de Ca em relação ao } \\
\text { controle }\end{array}$ \\
\hline Controle & 32.396 & 26.385 & & \\
\hline BS & 31.520 & 26.792 & $-2,7$ & 1,54 \\
\hline BSO & 32.875 & 29.086 & 1,47 & 10,23 \\
\hline BSSO & 38.139 & 26.064 & 17,72 & $-1,21$ \\
\hline
\end{tabular}

Fonte: Autoria própria (2017).

Entre os minerais envolvidos na nutrição das plantas de tomateiro, o potássio é o macronutriente extraído do solo em maior quantidade, seguindo pelo nitrogênio, 
cálcio, enxofre, potássio e magnésio (FERRARI, 2008). O potássio é absorvido pelas plantas na forma iônica $\mathrm{K}^{+}$e cerca de $75 \%$ do potássio total da planta encontra-se na forma solúvel $\left(\mathrm{K}^{+}\right)$. Esse macronutriente é responsável por garantir com a atividade enzimática, atuando como ativador de enzimas e aumentando a atividade metabólica das células das plantas. O nutriente também atua na abertura e fechamento dos estômatos durante a fotossíntese. O cálcio também é absorvido pelas plantas na sua forma iônica $\mathrm{Ca}^{2+}$ e grande parte desse macronutriente está contido nas plantas na forma de pectato de cálcio, sendo que alta proporção do Ca é encontrada na parede celular, atuando na manutenção e estrutura das membranas celulares e no alongamento e divisão celular do sistema radicular.

Outro fator pode ser associado ao crescimento das plantas como a presença da enzima triptofanase nas bactérias endófitas, sucedendo em prova positiva para indol, uma das principais substâncias envolvidas na síntese do ácido indolacético. O principal efeito do ácido indolacético (AIA) é promover o crescimento das raízes e caules através do alongamento celular e, dependendo da sua concentração, pode atuar acelerando o processo de divisão celular.

\section{CONSIDERAÇÕES FINAIS}

De acordo com os resultados obtidos, pode-se afirmar que os métodos de aplicação das bactérias endofíticas foram promissores, permitindo a colonização dos tomateiros pelos isolados endófitos. Observou-se que o tratamento com as bactérias na semente e no solo (BSSO) demonstrou melhores resultados no que diz respeito à concentração de minerais e altura das plantas, podendo atribuir esses resultados à capacidade das bactérias endófitas em promover maior absorção de nutrientes e a síntese de fitohormônios relativos ao crescimento vegetal, como o AIA. Constatamos que a exposição das sementes às bactérias (BS) prejudicam o desenvolvimento inicial da planta, retardando seu crescimento, mesmo apresentando número aumentado de bactérias por grama de planta e compensando os níveis de $\mathrm{Ca}^{2+}$ e de $\mathrm{K}^{+}$na planta adulta, o número de frutos foi reduzido para metade dos apresentados pelo grupo controle. Como perspectivas futuras poderia ser testado quantidades diferentes de bactérias na inoculação e desafiar as plantas com um parasita para verificar se há 
uma melhora em suas defesas através de um antagonismo microbiano. Ademais, o emprego de bactérias endofíticas para a promoção de crescimento do tomateiro, demonstra ser um processo economicamente viável em termos de obtenção dos microrganismos e custos de cultivo em laboratório, sendo também uma alternativa interessante para um público crescente de consumidores com foco no ambientalismo, por ser uma alternativa para diminuir o uso de fertilizantes mais agressivos ao ambiente.

\section{REFERÊNCIAS}

ANVISA - Agência Nacional de Vigilância Sanitária. Programa de Análise de Resíduos de Agrotóxicos em Alimentos (PARA). Nota técnica para divulgação dos resultados do PARA de 2008. Brasília: ANVISA, 2009. Disponível em: $<$ http://portal.anvisa.gov.br/programa-de-analise-de-registro-de-agrotoxicos-para> Acesso em: 01 jul. 2018.

ANVISA - Agência Nacional de Vigilância Sanitária. Programa de Análise de Resíduos de Agrotóxicos em Alimentos (PARA). Relatório das análises de amostras monitoradas no período de 2013 a 2015. Brasília: ANVISA, 2016. Disponível em: < http://portal.anvisa.gov.br/programa-de-analise-de-registro-de-agrotoxicos-para> Acesso em: 01 jul. 2018.

ASSUMPÇÃO, L. C. Diversidade da comunidade bacteriana endofítica de sementes de soja e o seu potencial biotecnológico. 2009. 93 f. Dissertação (Mestrado em Agronomia) - Universidade de São Paulo, Escola Superior de Agricultura Luiz de Queiroz, Piracicaba, 2009. Disponível em:< http://www.teses.usp.br/teses/disponiveis/11/11138/tde-10022009-154643/ptbr.php>. Acesso em: 02 jul. 2018.

AZEVEDO, J. L. Microrganismos endofíticos. Departamento de Biologia Geral, UFG, Disponível em: $<$ https://www.agencia.cnptia.embrapa.br/Repositorio/Azevedo_Microrganismosendofi ticos_000fdrap80702wx5eo0a2ndxyo89f39n.pdf>. Acesso em: 01 jul. 2018. 
BARRETTI, P. B. et al. Bactérias endofíticas como agentes promotores do crescimento de plantas de tomateiro e inibição in virtro de Rastonia Solanacearum. Ciênc. agrotec., Lavras, v. 32, n. 3, p. 731-739, maio/jun. 2008. Disponível em: < http://www.scielo.br/pdf/cagro/v32n3/a05v32n3.pdf>. Acesso em: 21 maio 2018.

BARRETTI, Pa. B. et al. Seleção de bactérias endofíticas de tomateiro como potenciais agentes de biocontrole e de promoção de crescimento. Ciênc. agrotec., Lavras, v. 33, Edição Especial, p. 2038-2044, 2009. Disponível em: < http://www.scielo.br/pdf/cagro/v33nspe/57.pdf>. Acesso em: 23 abril 2018.

CARMO, Ciríacia Arcangela Ferreira de Santana de. et al. Métodos de análise de tecidos vegetais utilizados pela Embrapa Solos. Rio de Janeiro: Embrapa Solos, 2000

p.

Disponível em:

https://www.infoteca.cnptia.embrapa.br/bitstream/doc/337672/1/Metododeanalisedet ecido.pdf>. Acesso em: 16 ago. 2018.

EMPRESA BRASILEIRA DE PESQUISA AGROPECUÁRIA - Embrapa. Cultivo do tomate para industrialização. 2ª ed. Versão Eletrônica. Embrapa Hortaliças, 2006. Disponível em: https://sistemasdeproducao.cnptia.embrapa.br/FontesHTML/Tomate/Tomatelndustria I_2ed/. Acesso em: 20 nov. 2018.

LOPES, C. A.; ÁVILA, A. C. Doenças do Tomateiro. Brasília, DF: Embrapa Hortaliças, 2005. 151 p. Disponível em: < https://www.embrapa.br/busca-depublicacoes/-publicacao/778171/doencas-do-tomateiro>. Acesso em: 30 jun. 2018.

MARIANO, R. de L. R. et al. Importância de bactérias promotoras de crescimento e de biocontrole de doenças de plantas para uma agricultura sustentável. Anais da Academia Pernambucana de Ciência Agronômica, Recife, 2004. p. 89-111. v. 1.

Disponível em:

https://ainfo.cnptia.embrapa.br/digital/bitstream/item/34111/1/AAPCA-V1-Revisao04.pdf>. Acesso em: 20 nov. 2018. 
RICHTER, Ana Simone et al. Produção de tomate orgânico em cultivo protegido Aspectos práticos e teóricos. Governo do Estado do Paraná. Centro de Referência em Agroecologia - CRPA. 40 p. Disponível em: < www.cpra.pr.gov.br/arquivos/File/CartilhaTomate.pdf >. Acesso em: 2 jun. 2018.

ROMEIRO, R. S; HALFELD-VIEIRA, B. A.; MIZUBUTI, E. S.G. Métodos de isolamento de bactérias do filoplano de tomateiro visando populações específicas e implicações como agentes de biocontrole. Fitopatol. Bras., Brasília, v. 29, n. 6, p. 638-643, nov./dez. 2004. Disponível em: <http://www.scielo.br/pdf/fb/v29n6/a07v29n6.pdf>. Acesso em: 21 maio 2018.

SANTOS, Taides Taveres dos; VARAVALLO, Maurilio Antonio. Aplicação de microrganismos endófitos na agricultura e na produção de substâncias de interesse econômico. Semina: Ciências Biológicas e da Saúde, Londrina, v. 32, n. 2, p. 199-212, jul./dez. $2011 . \quad$ Disponível em: <http://www.uel.br/revistas/uel/index.php/seminabio/article/view/8241>. Acesso em: 03 abril 2018.

TORTORA, Gerard J.; FUNKE, Berdell R.; CASE, Christine L. Microbiologia. 12. ed. Porto Alegre: Artmed, 2017.

Enviado: Dezembro, 2020.

Aprovado: Junho, 2021. 